CATALAN REVIEW

Catalan Review

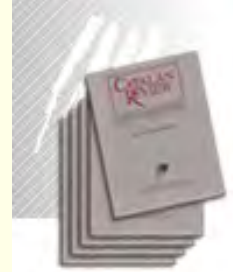

You are accessing the Digital Archive of the Catalan Review Journal.

By accessing and/or using this Digital Archive, you accept and agree to abide by the Terms and Conditions of Use available at http://www.nacs-

catalanstudies.org/catalan review.html

Catalan Review is the premier international scholarly journal devoted to all aspects of Catalan culture. By Catalan culture is understood all manifestations of intellectual and artistic life produced in the Catalan language or in the geographical areas where Catalan is spoken. Catalan Review has been in publication since 1986 .
NORTH

AMERICAN

CATALAN

SOCIETY
Esteu accedint a l'Arxiu Digital del Catalan Review

A l' accedir i / o utilitzar aquest Arxiu Digital, vostè accepta i es compromet a complir els termes i condicions d'ús disponibles a http://www.nacs-

catalanstudies.org/catalan review.html

Catalan Review és la primera revista internacional dedicada a tots els aspectes de la cultura catalana. Per la cultura catalana s'entén totes les manifestacions de la vida intel lectual i artística produïda en llengua catalana o en les zones geogràfiques on es parla català. Catalan Review es publica des de 1986.

\title{
Western narratives of eastern adventures: The cultural poetics and politics of catalan expansion, 1300-1500 Roberto J. Gonzalez-Casanovas
}

Catalan Review, Vol. VIII, number 1-2, (1994), p. 211-227 


\section{WESTERN NARRATIVES OF EASTERN ADVENTURES: \\ THE CULTURAL POETICS AND POLITICS \\ OF CATALAN EXPANSION, 1300-I500}

ROBERTO J. GONZÁLEZ-CASANOVAS

\section{INTRODUCTION: HISTORY AND FICTION IN CATALAN AGES OF EXPANSION}

The literary interpretations of Byzantine history undertaken by $\mathrm{Ca}$ talan authors in the thirteenth to fifteenth centuries correspond to the age of Aragonese expansion in the Mediterranean. This essay applies the methods of cultural historicism (as practiced by Greenblatt and Montrose in Veeser's anthology, as well as by Said) and of the rhetorical and mythopoetic analysis of historical literature as propaganda (as established by Hampton, Stierle, and White), to Ramon Muntaner's Crònica (1325-1328) and Joanot Martorell's and Martí Joan de Galba's Tirant lo Blanc (I460-I490). These narratives, as history and historical fiction, deal with crusader knights and mercenary soldiers from Aragon and Sicily (from the almogàvars led by Roger de Flor to later soldier-adventurers before the fall of Constantinople) who fight to protect Byzantium from the Turks and to create new Western territories in the East. My purpose is to establish a critical framework for comparing Muntaner and Martorell as historical narrators and cultural interpreters.

The present study forms part of a series of interpretative essays on the propagandistic role within Catalan historiography (chronicles and novels) of Western heroes in the Catalan and Muslim East (see González-Casanovas 1991, 1993, 1994). These studies consider the problematic ways in which the very concept of Christendom should be defined according to three levels of culture: first, the ideological code of cultural identity, similarity/opposition, and superiority/inferiority should be considered in the contexts of Mediterranean Western «Latin» and Eastern «Greek» traditions; second, the literary strategies of Catalan historiography and narratology about Byzantine wars or crusades should be interpreted according to the cultural politics of such issues as ethnicity, religious authority, geography of warfare, and sociology of élites; third, the evolving interpretations of Byzantine history (medieval to Renaissance) by Western authors should be related to the cultural poetics of mythic texts. The cultural analysis of 
Catalan historical writers (chroniclers and romancers) shows that "Christendom" functions as a complex social and rhetorical phenomenon.

In 1992 scholars observed the quincentennial of Columbus' voyage of discovery of 1492 by considering the encounter of Old and New World cultures, as well as the expansion of the new European nationstates, especially Spain and Portugal, westward across the Atlantic. But in the case of the Iberian kingdoms of Castile and Aragon such cultural encounters and ages of expansion represent only the last stages of a series of explorations, exchanges, rivalries, and conquests that first unfold across the Mediterranean itself over a period of two and a half centuries. This has been stressed by the historian Felipe Fernández-Armesto in his book Before Columbus: Exploration and Colonisation from the Mediterranean to the Atlantic, 1220-1492. For him overseas expansion lies at the heart of the development of the great dynastic power of the medieval House of Aragon:

[T] he loose dynastic agglomeration that constituted the Arago-Catalan world of the thirteenth and fourteenth centuries was meant to function cohesively, as a kind of fraternal alliance, a tenuous confederacy bound more by atavistic appeals to loyalty and the force of oaths than by common institutions... [T] he kinship of the dominions of the House of Barcelona was something in which its subjects seem to have believed..., and none more so than Ramon Muntaner, whose entire chronicle was inspired by his king's vision of an end to fraternal dissension and something approaching a coalescence, if not a unification, of the Arago-Catalan world (Fernández-Armesto 4i).

It is precisely this question of the Catalan mythic history of its Mediterranean empire or, according to Hillgarth, "dynastic confederation," with its related terms of atavistic appeals, communal beliefs, and dynastic vision, that should serve to establish the parameters for the present study of Muntaner's chronicle and Martorell's novel. The propaganda of Aragonese prowess and heroism in an age of Western expansion and Eastern decline raises issues of interpretation that address the mythic textuality, social contexts, religious intertexts, and political subtexts of a national history. Catalan historiography (documentary or fictional) should be read as a system of stories that provide order, meaning, and value and serve to develop the community's sense of identity, worth, and power. 
2. WESTERN INTERPRETATIONS OF THE EAST: CULTURAL DOMINATION AND MISSION

Muntaner's and Martorell's accounts of Western military campaigns in the East, in alliance with the Byzantines and in opposition to the Turks, both take as their point of departure real historical events. The fourteenth-century chronicle represents an eyewitness account of the Germano-Italian Roger de Flor's and the Catalan almogàvars' victories against the Turks in Anatolia, intrigues in Constantinople, massacre at the hands of the Byzantine co-emperor in Salonica, revenge in Thrace, and conquest of Athens from the Franks. This leads to the creation of a Catalan enclave in the East which is nominally subject to the Aragonese house of Sicily:

Com los catalans se veeren així ordonats al ducat d'Atenes e senyors d'aquell país, ells trameteren llurs missatges al senyor rei de Sicília, que si a ell plaia un de sos fills trametre a ells, que ells lo jurarien per senyor e li lliurarien totes les forces que tenien ( $\mathrm{CM} \mathrm{c} 242 ; 2:$ I25).

The fifteenth-century novel reinterprets the earlier historical, and by now quasi-legendary figure of Roger de Flor (and also the later figure of John Hunyadi of Vlachia, defender of the Balkans from the Turks and regent of Hungary I $446-1458$ ), in such a way that it goes beyond the strict confines of Catalan history so as to develop the story of Tirant as heroic exemplar of the dominant West. Despite his protests to the contrary, Tirant and his chivalric company are the only ones who can rescue the decadent East from imminent conquest by the Turks:

[T] no só vengut ací, ab esforç de cavalleria, per poder ofendre a la gran morisma que en lo vostre Imperi és, car no som en nombre sinó cent quaranta cavallers e gentilshòmens, tots com a germans en voluntat, no volent nós res usurpar que de dret a nosaltres no sia dat justament, com a la majestat vostra sía notori jo no ésser mereixedor de tal dignitat ni capitania per moltes justes raons ( $\mathrm{TB}$ II7; 1; 219).

The novel records the dynamic flow of energy and influence from west to east that parallels the House of Aragon's own political and economic development as a Mediterranean power. It translates this historical phenomenon into the fictional terms of the Breton (not Catalan!) knight Tirant's formation in England, adventures in Sicily, exploits in Rhodes, romance and intrigue in Constantinople, captivity and campaigns in North Africa, and final victories and negotiations in Thrace. 
The historical and legendary aspects of Western heroism in the East are interpreted by biased narrators who are close to the centers of Catalan power. Ramon Muntaner (1265-1336), a non-noble from the Catalan heartland who becomes military governor of Gallipoli, civil governor of Djerba, citizen of Valencia, and mayor of Ibiza, represents the zealous campaigner and administrator whose loyalty, wherever he happens to find himself in the Mediterranean, is always to the House of Aragon and its many dynastic branches from the duchy of Athens to the kingdoms of Sicily, Valencia, and Mallorca, and the motherland of Catalonia itself. His loyalty, like that of the almogiavars with whom he fights, proves errant yet constant, as it extends across space and time:

Per tots temps qual que sia rei d'Aragó és molt tengut de bé a fer a la vila de Peralada...que en servii del senyor rei d'Aragó perderen tot quant havien. Que jo e d'altres...hi perdem gran res, e no hi som puis tornats per habitar, ans som anats per lo món cercant consell ab molt mal e treball e perills que n'havem passats, e la major part ne són morts en les guerres aquestes que la casa d'Aragó ha haüdes (CM c 125; i: 200).

Joanot Martorell (I413-I468), like his literary successor Martí Joan de Galba (died 1490), is a Valencian knight and courtier who reflects the international politics and cosmopolitan culture of the House of Aragon in the early Renaissance. It is when Alfons V (reign I4I6-I458) moves his court to the Catalan kingdom of Naples, that a Valencian merchant oligarchy develops social institutions and artistic expressions to rival any from northern Italy, and that Aragon attempts to seize the diplomatic and military momentum against the Turks, after Constantinople's fall in 1453, by seeking to create a new balance of power in the Mediterranean through alliances with or conquests of North Africa. This is mirrored in the historical fiction of the protagonist's self-conscious heroism, which projects the renewed chivalric and crusading ethos of Aragon in contemporary history:

Vull que et sia notori com la mia condició és de gentilesa, per bé que no sia príncep ni gran senyor; mas com a home jove desitjant adquerir honor i fama, he cercat lo món.... Do he nom Blanc..e les mies mans són restades esteses devers la lluna, per què demostra que jo, ab ajuda de la divina Potència, tinc de conquistar tota la Barbaria (TB c 30r; 2: 157-58).

True, it is in the contexts of different ages of Aragonese expansion that the historiography about the mercenary campaigns of the almogàvars in Muntaner's testimony and the idealized crusades of their chivalric successors in Martorell's fiction come to be interpreted. Ne- 
vertheless, what should be stressed is the basic similarity of their myth-making about Catalan or Western power: both chronicle and romance develop a cultural poetics in terms of historical narrative, heroic example, political mirror for princes and courtiers, and religious propaganda of crusade and mission.

The creative and interpretive dimensions of historiography, whether documentary or fictional, are readily apparent to those who have studied the social and political background of the so-called crusades of the mercenary-soldiers and knight-adventurers that are represented in Muntaner's chronicle and Martorell's novel. What the heroes of historical literature like Roger de Flor and Tirant lo Blanc often represent is the evolution of the crusades into the new realities of late-medieval Mediterranean power politics: shifting patterns of military professionalism, changing economies of regional and international warfare, attempts to regulate conflict while making it more rewarding, and a gradual establishment of geopolitical alliances and rivalries. As Delort observes,

The crusades were thus able to offer to unemployed warriors, even to certain peasants, a possibility of improving their situation, of recovering a fortune from share in booty, pillage, or, in the case of those who remained, a better redistribution of property. Perhaps the departure of professional combatants who were restless and greedy also allowed the truce of God to be better regulated and peace to be kept in the West by providing overseas the opportunity to employ their energy (Delort 8, my translation).

Although Delort's comments apply more directly to the almogàvars than to Tirant's companions, it is still the case that for Western soldiers and knights the Eastern Mediterranean provided a theater for war and a stage for heroism that often surpassed the opportunities available back home.

This type of military opportunity was for Catalan campaigners (and the non-Catalan adventurers who accompanied or led them) both quantitatively and qualitatively superior to that of the home territories during the centuries of greatest expansion of the House of Aragon. In the case of Muntaner's almogàvars, the Catalan readers are led to admire and sympathize with the heroic figure of Roger de Flor, whose exalted rank is earned not only by right of arms but also by virtue of his chivalry; this marks a contrast with the weak and treacherous Byzantines whom he would serve:

Tornaré a parlar del cèsar [Roger], qui s'aparellà ab tres-cents hòmens a cavall e mil hòmens de peu per anar a Andrinòpol a veer xor Miqueli, fill de l'emperador.... Açò faïa ell per gran llealtat...e per fina amor de dreta raon...; e 
cuidava's que així con ell era ple de tota lleialtat, que l'emperador e sos fills fossen aitals; e era tot lo contrari (CM c 215; 2: 85).

But it is repeatedly made clear by Muntaner that such great deeds and valor emerge as the result of an ordinary yet heroic soldier from the West (an ex-sergeant of the disbanded Templars) finding a series of extraordinary opportunities among Aragonese-Sicilian campaigners, Catalan almogàvars, and Greek crusaders that take him ever farther east (Sicily, Acre, Anatolia, Byzantium). Similarly, after the death of Tirant, who had become caesar (second-in-command) of the Eastern empire, his friend Hipòlit comes to surpass him by becoming emperor through marriage to the Greek empress:

[L]a divina Providència és estat plasent que vostra majestat resta senyora e regidora de tot l'Imperi grec.... [V]os suplicam e demanam de gràcia que façau lo que us consellam, e serà útil, honor e delit vostre, car vos darem tal marit que serà fet a tot lo plaer e consolació vostra, $\mathrm{e}$ tal cavaller que sabrà defendre la terra e serà parent del gloriós Tirant, que tots...ne seran molt contents e aconsolats (TB c 483; 2: 406).

The marriage of convenience of the young and valiant Hipolit with the old and weak empress thus comes to symbolize the nominal alliance of Western and Eastern interests against the Turks that leads to the "Latin" protection of Greek Christendom and domination of the whole Mediterranean. It is not literary hyperbole but historical fact that Western soldiers or knights in a short period of time did become great commanders and even caesars of the Byzantine empire, just as Western merchants became great bankers in Constantinople and carved out commercial colonies throughout the Aegean and Ionian seas. As a result of the establishment by treaty of the Italian trading centers in Byzantium from the twelfth century on and the founding by conquest of the «Latin" kingdoms and duchies in Greece after the fourth crusade of 1204 (when Western crusaders captured, sacked, and came to govern Constantinople), the center of career opportunities, social mobility, and heroic fantasies shifted toward the east. This historical and literary shift in effect would last until the posthumous publication of Tirant lo Blanc in 1490, just two years before Columbus' voyage would serve to reorient the West's energy, ambition, and imagination beyond the Mediterranean and across the Atlantic towards the newly discovered continents and newly conquered empires of the American Indies.

In addition to the historical dimensions of cultural politics in Muntaner's and Martorell's works, there are also important aspects to be considered about cultural poetics as it operates in the very textua- 
lity of history as story. Here it would be useful to refer to Hayden White's distinctions about the types of historiography:

[T] here are three basic kinds of historical representation-the annals, the chronicle, and the history proper.... While the annals represent historical reality as if real events did not display the form of story, the chronicler represents it as if real events appeared to human consciousness in the form of unfinished stories.... [T] he very distinction between real and imaginary events that is basic to modern discussions of both history and fiction presupposes a notion of reality in which athe trues is identified with "the real" only insofar as it can be shown to possess the character of narrativity (White 4-6).

For White, the third type, history proper, is a complete story that possesses narrative closure as well as political or moral exemplarity. As a result of applying such a model of historiography, it is important to note that, in spite of the diverse genres of (auto)biographical chronicle and historical novel that within the tradition of literary history correspond to Muntaner's Crònica and Martorell's Tirant, both works function as historical narratives about ages of Western expansion and conquest.

In effect, both works present complete stories that interpret for their contemporary audience what the new historicists term the discourse of power with reference to a master narrative of cultural domination of East by West and in relation to a heroic mythos of the rescue and renewal of all Christendom, Greek and Latin, from Islam by the new crusader-adventurers of the fourteenth and fifteenth centuries. In Muntaner, the story of Roger de Flor is that of a modern (late-medieval) hero's meteoric rise, which corresponds to the contemporary history of Aragon's own rapid expansion. What is more, this particular story and collective history, both filled with «true marvels," are ones which have unfolded and are still unfolding before living witnesses like the chronicler:

[T]ornar-vos he a parlar d'un valent hom de pobre afer, qui per sa valentia muntà, a pocs de temps, a més que null hom qui anc nasqués. E per ço vull parlar d'ell....car los afers seus... foren fets molt meravelloses e de gran cosa, e qui tots són reputats, e deuen ésser, al casal d'Aragon; e com, en partida, la cosa per què jo em són mogut a fer aquest llibre, és per les grans meravelles qui per ell se són mogudes e esdevengudes, e grans victòries que catalans e aragoneses han haüdes en Romania per lo seu començament. De les quals meravelles null hom no poria recontar la veritat con jo faç, que fui en Sicília, en la sua prosperitat, procurador general seu, e cabí en tots los seus afers majors que ell féu, e per mar e per terra; per què cascuns me'n devets creure ( $\mathrm{CM} \mathrm{c}$ 193; 2: 58). 
In Martorell, who is writing a century and a half later, just after the great catastrophe of Constantinople's fall to the Ottomans, there can be observed a tendency to exaggerate the role of extraordinary individual figures like Tirant and his small company of Western knights (only one hundred forty as opposed to over six thousand almogàvars), who struggle successfully against the great forces of momentous events, upon which the fate of all Christendom, as well as the geopolitical balance of the Mediterranean, are seen to depend. Ironically, the protagonist can combine the rhetorical bombast of a latter-day crusader, as he rallies his by now expanded troops to final, total victory, with the worldly-wise prudence of a Renaissance diplomat, as he tries to assure a just and lasting peace:

Més se deu considerar la molta glòria que obtendrem d'ésser vencedors, e lo gran premi que s'espera de Nostre Senyor Déu de posar en llibertat tant poble crestià en captivitat.... E més se deu considerar lo gran espant que serà en la morisma, oint dir com tots són morts o presos, e la grandíssima venjança que obtendrà per mitjà de nosaltres la corona imperial per les moltes ofenses i afliccions per ells donades, e serà venjança de la molta cavalleria que per causa llur en l'Imperi grec s'és perduda, e no-res-menys, morint tots aquests, haurem la pau més segura, e aterrament de tots los altres, e repòs tranquil.le a la corona del grec Imperi.... [M]as perquè conegau quanta és la humanitat $e$ clemència del senyor Emperador, és content...de fer pau e treva a cent e un any, e lliga e germandat ab lo Soldà e lo Turc, e valer-los sempre contra moros, mas no contra crestians (TB cc 427, 446; 2: 327-28, 349).

Thus the Realpolitik of securing the best interests of the Greek empire and its "Latin» champions for the foreseeable future throughout the region are used as counterweights to the zeal for conquest and thirst for vengeance that earlier are being roused against the traditional enemy of Christendom.

The transformation of history as factual events into history as meaningful experience in narrative, as well as the translation of history as past deed into history as archetypal example in myth, can be observed in the Catalan accounts of intervention in the East. For White, it is not the form but the content (formative process) that gives order, significance, and value to historical writing:

[N]arrative discourse, far from being a neutral medium for the representation of historical events and processes, is the very stuff of a mythical view of reality, a conceptual or pseudoconceptual «content» which, when used to represent real events, endows them with an illusory coherence.... To conceive of narrative discourse in this way permits us to account for its universality as a cultural fact and for the interest that dominant social groups have not only 
in controlling what will pass for the authoritative myths of a given cultural formation but also in assuring the belief that social reality itself can be both lived and realistically comprehended as a story (White ix-x).

As White maintains, historical textuality, as a culturally significant narrative and myth, embraces the literary phenomena of the formation and reception of history as story: it interprets the cultural situations of a particular communal identity, social organization, and political authority; it also enacts the cultural codes of a given people's folk tradition, religious belief, and philosophical ethics.

The preceding theoretical considerations can aid in the comparative reading of Muntaner and Martorell as historical narratives and cultural mythologies. What a historicist critique offers is a way of interpreting history and historical fiction in terms of the heroic code of cultural domination and the political code of cultural mission. These codes approximate the reception of these works by Catalan-speaking royal, aristocratic, and municipal élites in the various centers of influence of the House of Aragon throughout the Mediterranean. In the case of Muntaner's chronicle, the historical narrative is transformed into a political cursus by which the chronicler shows the growth of his military and administrative experience, proves his loyalty in deeds and words, and projects his worth to his lord and the dynastic crown of Aragon, in whose service he remains while he shifts to another regional sphere of interest, Djerba, off the coast of Tunisia:

[N]ós no havem en nostre regne negun qui, ab l'ajuda de Déu, nos hi pusca tan bon consell donar con vós [Muntaner], per moltes raons, e assenyaladament per ço con vós havets més vist e oït en guerres que hom que sia en nostra terra; e d'altra part, que havets llong de temps senyorejada gent d'armes, e sabets con fan a comportar; d'altra part, que sabets de sarraïns e parlar sarraïnesc, per què podets fer vostres afers menys de torsimany, així en espies con en altres coses, en la illa de Gerba; e moltes d'altres raons... (CM c 25I; 2: 137).

In the case of Martorell's novel, the historical narrative is twice transposed: once at the beginning, in a shift from the chivalric associations of the romancer's Britain (the prologue with its reworking of the Guy of Warwick tradition) to the contemporary intrigues of Byzantium and wars against the Turks, and once at the end, with a shift back to the heroic legends of a timeless Brittany (epilogue):

[A] l'entorn per los extrems d'aquella [tomba], de lletres gregues buidades de fin or, se llegien tals paraules: "Lo cavaller que en armes fon lo fènix i la que fon de totes la pus bella, morts són ací en esta xica tomba, dels quals lo 
món ressona viva fama: Tirant lo Blanc i l'alta Carmesina"... No es poria per llengua expremir les grandíssimes solemnitats que foren fetes en Bretanya en la sepultura de Tirant, car per lo duc de Bretanya e la Duquessa, e per tots los parents de Tirant fon fet molt gran dol de la sua mort com saberen los actes d'immortal recordació que per ell eren estats fets, e la gran prosperitat en què pujat era (TB cc 485-86; 2: 409-10).

Yet what is to be fixed in Tirant's own legend as part of a faraway monument to chivalry is but an imaginative sublimation in time and space of the real history of modern acts (great and powerful, if not heroic) of war and commerce that the House of Aragon, especially Valencia, have witnessed in the most recent generations. The ambivalent discourse of power emerges from relating crusading or chivalric ideals in exemplary stories to the complex geopolitical and administrative conditions of recent history. This discourse underscores the hybrid nature of such historical narratives that combine the forms of heroic legend, aristocratic example, military manual, and political propaganda.

For Muntaner and Martorell cultural domination involves the historiographic phases of translation and appropriation. As each hero penetrates into the new cultural contexts of crusading warfare and court politics in Byzantium, he comes to represent a translatio imperii, not simply from east to west, but from the reconquest crusade of the West to the expansionist conquests of the New Latin West established in the midst of Greek and Islamic territories of the eastern Mediterranean. In effect each narrator shows this translatio in the manner in which the protagonist reinterprets Western codes of heroism in the contexts of Byzantine military and court institutions and reenacts Eastern rituals of authority for reception by his own countrymen and peers. Once Roger de Flor the mercenary has fulfilled his heroic exploits by using in Anatolia all the skills he acquired in his Sicilian campaigns, Muntaner shows the reward for his services and recognition of his status in the assimilation of the Byzantine symbols of power associated with the ranks of grand duke and caesar (CM cc 199 and 212). Similarly, once Tirant the knight has won fame for his military prowess both in the West and in the East, Martorell shows his integration into the command of Byzantine defenses as captain general and his assumption of royal rank as caesar, son-inlaw, and successor to the Emperor (TB cc 122 and 453). Yet in both cases, the translatio implies a transference of heroic energy from an Eastern figurehead to a powerful Western commander and a transposition of cultural ideology from the empty form of Greek court ceremonial to the renewed manifestations of Latin military and 
political power. Roger becomes in fact a caesar, Tirant acts as a true captain.

For Muntaner and Martorell cultural mission consists of mythichistorical models of reform and justice. As each hero attempts to impose order upon his own conquests and renegotiate his relationship with the Byzantine court, he comes to articulate a critique of power, not in terms of court intrigues in opposition to frontier arms, but rather of what are perceived to be the decadent structures and practices of the East. The latter are to be reconstructed by means of a Western feudal-chivalric order and reevaluated with respect to a secularized notion of ethics (civic or chivalric), which is then transforming latemedieval Christendom into a more political (authoritatively and juridically defined) and less religious (spiritually or morally conscious) community. Once Roger de Flor as new caesar has won autonomy for his conquered territories from the Emperor, only to be assassinated by the Byzantines in Adrianople, Muntaner stresses that his successors intend to enact a reorganization of his lands and peoples according to Catalan concepts of military and civil government. Such reform is to begin with the application of justice against the emperor himself:

[N]ós haguem d'acord que abans que faéssem mal a l'emperador, que el desfiàssem e el reptàssem d'açò que fer-nos havia fet; e que aquest desafiament, e puis lo reptament, se faés en Contastinoble en presència del batlliu del comun de Venècia, e del comun de Pisa e del capità del comun de Gènova, e tot ab cartes públiques (CM c 216; 2: 87).

It is only after the Byzantines respond with the massacre of Catalan leaders and troops in Constantinople that the almogàvars abandon juridical recourse and, duly empowered by divine wrath, enact their bloody vengeance: «fo feta a avant tan gran venjança per la companya, ab l'ajuda de Déu, que jamés tan gran venjança no fo feta» (CM c 217; 2: 87). All the while, the chronicler develops an opposition of mentalities, customs, and interests between the corrupt Romania of the Emperor and the reformed Anatolia of the Caesar that in effect serves to distinguish the false promises and bad coin of the moribund Greek Empire from the true obligations and real wealth of the new Latin Empire (CM c 212). Similarly, once Tirant as the new commander of the crusaders has established his credentials as a worthy knight of the Order of the Garter, Martorell shows how he comes to exercise the prudence of a courtier against the luxuries and intrigues of the court with its empty titles and privileges (TB c 117 ). At the same time Tirant comes to apply the rule of justice according to a universal et- 
hics that corresponds more to a Renaissance humanism than to the medieval crusade. In effect he comes to transcend distinctions between Christian or Islamic political interests as he learns to value the worldly wisdom, rather than traditional interests or biases, of fellow commanders and statesmen on both sides of the frontier. Thus Tirant listens to Abdullah Solomon's good counsels:

¡Com quant de major llaor és justament e temprada regir un regne, que guanyar e aconseguir-lo benaventuradament!... Tu has vençuda l'adversa [fortuna]; guarda't ara, car la pròspera torna a encontre de guerra.... E no et penses que per ço com ha mudat armes te sia benigne ne pus flac, ans te serà bé mester que t'abilles de novelles armes.... [M]olts qui foren en llurs adversitats forts foren per la fortuna pròspera enderrocats.... E sovint és la pau pus perillosa que la guerra (TB c 143; 1: 296).

New contrasts are being made: between conquest and government, between fortune(s) and justice. New arts of war and rules of peace have now displaced the medieval holy war and peace of God.

Having noted earlier the ways in which Muntaner and Martorell develop an ambivalent discourse of power, it should be pointed out that their ambivalence also reflects the self-conscious reference to their particular age of expansion as an era of transition for their culture and period of transformation for its values. Muntaner writes a century after the climax of Jaume I's reconquest from the Moors of the whole of the eastern Iberian coast and neighboring islands (from $\mathrm{Ma}$ llorca in 1229 to Valencia in 1238) and in the middle of the new Catalan conquest of Sicily (by Pere III in I282) and Sardinia (by Jaume II in 1323-24). These reconquests and conquests lead not only to an opening up of the Mediterranean to Catalan interests but also to a shift in initiative from warrior kings and crusader knights to citizen-merchants, soldier-adventurers, and royal administrators. Martorell begins to write in Valencia towards the end of Alfons V's reign (1416-1458), centered at the Catalan court of Naples, which is a period that witnesses new Catalan conquests in Italy (Naples in 1443), interventions in Rhodes (Jaume Vilaragut and others in a defense against the Turkish siege of (443), and negotiations with local Christian and Muslim rulers of the eastern Mediterranean (I45I) before the fall of Constantinople in 1453. For Martorell's contemporaries it represents an age of renewed power for the House of Aragon, climaxing with the dynastic union with Castile in 1479 to create Spain as one of the strongest nation-states in Europe, that contrasts with the rapid decline and demise of the millenarian empire of Byzantium. To borrow a term applied to the Ottoman empire in the twentieth-century histories of the Balkan 
Wars and World War I, it can be said that in the late Middle Ages and early Renaissance it was the Greek East that appeared as the «sick man of Europe." This was in part due to its progressive fragmentation at the hands of Italian merchants and Frankish knights and to its rapid disintegration under the onslaught of the Ottomans. In great part it was also due to the marked contrast with what was perceived to be the new robustness of a West that was just beginning to flex its muscles first in the Mediterranean and then in the Atlantic.

\section{CONCLUSION:}

\section{CULTURAL AUTHORITY AND RECEPTION}

Any study of the propagandistic role of the Byzantine career of Western heroes in Catalan history and fiction should take as its point of departure and return the ways in which the very concept of Christendom is understood: How is it defined in relation to the religious contexts of crusade and mission? How is it exemplified with reference to new types of mythic heroism? And how is it interpreted according to the political subtexts of expansion and domination? The complex phenomenon of Christendom should be analyzed according to three levels of culture: (I) The anthropological complex of cultural identity, in terms of similarity/opposition and superiority/inferiority, serves as a key to understanding the ways in which the geographic and historical encounters between Mediterranean Latin and Byzantine Greek traditions give shape to histories of conquest and stories of adventure. (2) The literary strategies of Catalan historiography and mythography about the Byzantine wars and crusades are seen to correspond to the cultural poetics of such forms as ethnic or national legends, chivalric or civic mirrors of rulers, and religious propaganda for reconquest or reform. (3) The ideological interpretations of Byzantine history by Western authors (from late-medieval to early-Renaissance) come to reflect the cultural politics of the texts in terms of the geography of warfare, legitimacy of empires, and sociology of élites.

What emerges from a cultural historicist critique is that in the period from 1300 to 1500 , Christendom is being subjected to geographic and historical reconstructions, as well as ideological and mythic revisions. Muntaner's reference to the overseas exploits of the those who fight for the House of Aragon and Martorell's idealization of international orders of chivalry that are transforming the old crusades into modern campaigns are each designed to appeal to contemporary $\mathrm{Ca}$ talan or Valencian audiences of aristocratic and municipal élites. It is thus useful to compare Muntaner's chronicle and Martorell's novel in 
terms of similar forms of cultural propaganda that serve to record and interpret significant shifts in the power relationships between West and East in the Christian-Islamic Mediterranean.

Cultural politics and poetics play a key role in the mythopoetic writing of history and in the ideological interpretation of historiography. This can be shown in the manner in which the Catalan intervention in the Greek empire has been understood in both partisan and hostile terms by contemporaries and by modern scholars. The historian A. A. Vasiliev has summarized the contradictory perceptions of the Catalan role in Byzantine history and legend:

[W] hile a participant of the expedition, the Catalan chronicler Muntaner described Roger and his companions as courageous and noble fighters for a right cause, a credit to their country, Greek historians [George Pachymeres] consider the Catalans pillagers and insolent ruffians... The Athenian Duchy of the Catalans established by mere accident in the fourteenth century and organized upon Spanish or Sicilian models, has generally been considered a harsh, oppressive, and destructive government, which at Athens and in Greece in general has left very few material traces of its domination.... [T]n Greek popular tradition and in the Greek tongue there still linger reminiscences of the cruelty and injustice of the Spanish invaders.... But recently much new material, especially in the Archives of Barcelona (the archives de la Corona $d^{\prime}$ 'Aragó), has come to light which shows that the conception of former historians on this subject was biased. The years of the Catalan domination in middle Greece in the fourteenth century were not only troubled and destructive; they were also productive. The Acropolis...was fortified; for the first time since the closing of the Athenian school by Justinian the Great, a university was established at Athens. Catalan fortifications were also erected in middle and northern Greece (Vasiliev 6o5-8).

The various ways of commenting upon Catalan military interventions, commercial relations, cultural interactions, and literary interpretations in the Greek East can thus serve as a touchstone for popular and critical conceptions of the culture of imperial power in ages of decline or expansion.

A cultural historicist reading of Muntaner's chronicle and Martorell's novel points to the self-conscious triumph of a modern Western power in the Mediterranean at the dawn of the Renaissance. These works serve to rationalize the Realpolitik of Western dominance of territories in the Greek empire, such as the Catalan duchy of Athens, as well as to exemplify chivalric virtue by Western élites in the defense of the Christian East (Byzantine and Latin) from the Turks. In Muntaner's and Martorell's accounts, it is precisely in the Byzantine mirror of Christendom that Western chivalry's self-image is histori- 
cally framed, heroically reflected, politically and religiously challenged, and ultimately re-formed as an official ideology and a popular textuality. For the Catalan chronicler and romancer, the history of Western military interventions in the East offers not only models of enterprise, strategy, and valor for the evaluation of a period of national formation and expansion, but also a historically-conscious, «modern" way of understanding the evolution of the crusades within the Islamic and Greek East into imperial wars for control of the whole Middle East. As heroic legend and modern history, these Catalan works should be read in the West as mythical stories, propagandistic tracts, and exemplary lessons on Christendom's own survival and gradual transformation in a new age of world powers that are struggling for empire and hegemony.

\section{ROBERTO J. GONZÁLEZ-CASANOVAS UNIVERSITY OF KENTUCKY}

\section{WORKS CITED}

\section{A. Texts}

$\mathrm{CM}=$ Muntaner, Ramon. Crònica. 2 vols. Ed. M. Gustà. Barcelona: Edicions 62, 1979.

TB = Martorell, Joanot and Martí Joan de Galba. Tirant lo Blanc. 2 vols. Ed. M. Riquer. Barcelona: Edicions 62, 1983.

\section{B. Studies}

Delort, Robert, ed. Les Croisades. Paris: Seuil, 1988.

FernANDeZ-Armesto, Felipe. Before Columbus: Exploration and Colonisation from the Mediterranean to the Atlantic, 1229-1492. London: Macmillan, 1987.

GONZALEZ-CASANOVAS, Roberto J. "Catalan Interpretations of the Eastern Mediterranean, 1450-90: Cultural and Political Myths.» In Catalan Contexts of 1492 [Catalan Symposium 3]. Ed. J. M. SolàSolé. New York: Peter Lang, Catalan Studies, 1994 [in press].

- «History as Myth in Muntaner's and Martorell's Story of (Re)conquest.» In "Tirant lo Blanch*: Text and Context [Catalan Symposium 2]. Ed. J. M. Solà-Solé. New York: Peter Lang, Catalan Studies, 1993: 7I-9I.

- "Religious and Cultural Politics in Tirant lo Blanc.» Catalan Review 5, I (1991): 95-I2O. 
Hampton, Timothy. Writing from History: The Rhetoric of Exemplarity in Renaissance Literature. Ithaca: Cornell UP, 1990.

Hillgarth, J. N. \&The Crown of Aragon: A Mediterranean Empire?» The Spanish Kingdoms, Oxford: Clarendon, 1976, I: 233-86.

- The Problem of a Catalan Mediterranean Empire, 1220-1327. English

Historical Review, Supplement 8 (1975): 1-54.

SAID, Edward W. Orientalism. New York: Random House, 1978.

STIERLE, Karlheinz. «L'Histoire comme exemple, l'exemple comme histoire.» Poétique 3 (1972): 176-198.

VAsiliev, A. A. "Spanish (Catalan) Companies in East.» $A$ History of the Byzantine Empire. Madison: U of Wisconsin P, 1982, 2: 604-8.

VeESER, H. Aram, ed. The New Historicism. New York: Routledge, 1989.

WHITE, Hayden. The Content of the Form: Narrative Discourse and Historical Representation. Baltimore: Johns Hopkins UP, 1987.

\section{WORKS CONSULTED}

ABU-LughOD, Janet L. Before European Hegemony: The World System A. D. 1250-1350. Oxford: Oxford UP, 1989.

AYLWARD, Edward. Martorell's «Tirant lo Blanch»; Program for Military and Social Reform. Chapel Hill: U of North Carolina P, 1985. Bisson, Thomas N. The Medieval Crown of Aragon. Oxford: Oxford UP, 1986.

Boenne, Patricia J. The Renaissance Catalan Novel. Boston: Twayne, 1989: 86-123.

BudA, Milada. Medieval History and Discourse: Toward a Topography of Textuality. New York: Peter Lang, 1990.

BURKE, Peter, ed. New Perspectives on Historical Writing. University Park: Pennsylvania State UP, 1992.

ENTWISTLE, William J. «Tirant lo Blanc and the Social Order of the End of the Fifteenth Century.» Estudis Romànics 2 (1949-50): 149-64.

KeightLeY, R. G. «Muntaner and the Catalan Grand Company.» Revista Canadiense de Estudios Hispánicos 4, I (1979): 37-58

LAIOU, Angeliki E. Constantinople and the Latins: Foreign Policy of Andronicus II. Cambridge, MA: Harvard UP, 1972: 127-242.

McNerneY, Kathleen. Tirant lo Blanc Revisited. Detroit: Michigan Consortium for Medieval and Early Modern Studies, 1983.

PHILLIPS, J. R. S. The Medieval Expansion of Europe. Oxford: Oxford UP, 1988. 
RIQUER, Martín de. «Joanot Martorell». Història de la literatura catalana. Barcelona: Ariel, 1964, 2: 632-72I.

- «Ramon Muntaner.» Història de la literatura catalana. Barcelona: Ariel, 1964, I: 449-80.

RUBió LluCH, Antonio. La expedición y dominación de catalanes en Oriente juzgada por los griegos. Barcelona: Real Academia de Buenas Letras, 1883.

Setton, Kenneth M. The Catalan Domination of Athens, $131 \pi-1388$. London: Variorum, 1975.

SOBRÉ, Josep Miquel. L'èpica de la realitat: L'escriptura de Ramon Muntaner i Bernat Desclot. Barcelona: Curial, 1978.

VIERA, David J. «The Chronicle of Muntaner», Medieval Catalan Literature. New York: Twayne, 1988: 48-55.

YATES, Alan. «Tirant lo Blanc: Ambiguous Hero.» Hispanic Studies in Honour of F. Pierce. Sheffield: U of Sheffield, 1980: 181-98. 